\title{
Short-term residence, home range size and diel patterns of the painted comber Serranus scriba in a temperate marine reserve
}

\author{
D. March ${ }^{1, *}$, M. Palmer1 ${ }^{1}$ J. Alós ${ }^{1}$, A. Grau ${ }^{2}$, F. Cardona ${ }^{1}$ \\ ${ }^{1}$ Instituto Mediterráneo de Estudios Avanzados, IMEDEA (UIB-CSIC), Miquel Marqués 21, 07190 Esporles, \\ Islas Baleares, Spain \\ ${ }^{2}$ Laboratori d'Investigacions Marines i Aqüicultura, LIMIA, Eng. Gabriel Roca 69, 07157 Port d'Andratx, \\ Islas Baleares, Spain
}

\begin{abstract}
We examined the short-term movements of a small temperate fish, the painted comber Serranus scriba (Linnaeus 1758), within the marine protected area (MPA) of Palma Bay (NW Mediterranean) using passive acoustic telemetry. Fifteen adults were surgically implanted with acoustic transmitters and monitored between July 2007 and February 2008 for periods of up to 36 d. Interindividual variability was detected for both spatial and temporal patterns. There were 2 principal movement behaviours that were recorded, with some individuals showing high site fidelity and others showing a more mobile behaviour, moving out from the monitoring area. Observation-area curves indicated that a period between 3 and $5 \mathrm{~d}$ was required to determine home ranges of the sedentary fish. Home range sizes were small, with a minimum shift of core areas occurring on a daily basis. Total minimum convex polygon (MCP) areas ranged between 0.102 and $0.671 \mathrm{~km}^{2}$, whereas $95 \%$ kernel utilization distributions (KUD) ranged between 0.760 and $1.333 \mathrm{~km}^{2}$. Core areas (50\% KUD) ranged between 0.175 and $0.294 \mathrm{~km}^{2}$. There were no significant differences in home range patterns between day and night periods. However, the use of the continuous wavelet transform (CWT) revealed diel rhythms on the detection pattern that could be related to a resting behaviour at night. Estimation of home ranges of $S$. scriba agrees with the sedentary habits of the Serranidae family and suggests the potential use of MPAs for the sustainable development of the fishery of this small Serranid.
\end{abstract}

KEY WORDS: Acoustic tracking · Painted comber · Serranus scriba $\cdot$ Serranidae $\cdot$ Home range · Continuous wavelet transform $\cdot$ Diel pattern $\cdot$ Seagrass

Resale or republication not permitted without written consent of the publisher

\section{INTRODUCTION}

The spatio-temporal behaviour of fish is relevant to a number of marine management and conservation issues (Pittman \& McAlpine 2003, Botsford et al. 2009). For example, fish movements and home ranges are important factors to consider in the development of marine protected areas (MPAs). The benefits of a marine reserve are dependent upon the rate and scale of movement of species in relation to the reserve size (Kramer \& Chapman 1999, Sale et al. 2005). To provide effective protection, MPAs must be large enough to enclose the appropriate habitats and contain regular movements of target species (i.e. their home range), but also to allow dispersal and cross-boundary movements of early life stages to fishing grounds (i.e. spillover: Kramer \& Chapman 1999, Bartholomew et al. 2008). In addition, site fidelity is also related to the use of fish as bioindicators, as sedentary species are more suitable for representing local exposure to human impacts (Burger \& Gochfeld 2001). Moreover, the temporal variability of fish behaviour is relevant for surveys of abundance. Temporal variability can operate over annual or seasonal time scales (i.e. spawning 
aggregations), but more subtle variations that operate over short time scales of hours to days (i.e. feeding or sheltering) may also affect fish abundance estimates (Naylor 2005, Willis et al. 2006). Examining how individuals use space can reveal the diversity of behaviours within a species and can increase our understanding of basic ecological processes.

Acoustic telemetry has been used as an alternative to or as a complementary method for traditional mark and recapture studies to study fish movements (Voegeli et al. 2001, Parsons \& Egli 2005). This technology has allowed researchers to quantify home ranges within MPAs (e.g. Lowe et al. 2003, Parsons \& Egli 2005), to determine site fidelity (e.g. Collins et al. 2007, Abecasis \& Erzini 2008) and to infer temporal patterns of marine organisms (Jadot et al. 2006, Jorgensen et al. 2006). In this technique, an acoustic transmitter is attached to an individual and the acoustic signal is received by a hydrophone. Recent developments have allowed the use of transmitters in smaller fish. The tracking process can be active (i.e. boat tracking with a directional hydrophone) or passive (i.e. deploying submersible omnidirectional receivers). Automated systems that use arrays of acoustic listening stations have become a popular tool (Heupel et al. 2006). These passive systems can be designed to monitor simultaneous individual movements at a broad range of spatial and temporal scales in order to infer spatial (i.e. home range) and temporal (i.e. diel activity) movement patterns.

The painted comber Serranus scriba (Linnaeus 1758) is a littoral benthic fish that is distributed along the coasts of the Mediterranean and the Black Sea, as well as in the eastern Atlantic Ocean from the Bay of Biscay to Mauritania (Bauchot 1987). This species can be found from the intertidal zone to depths of $150 \mathrm{~m}$, although it is more common at $<20 \mathrm{~m}$ (Fasola et al. 1997) where it inhabits rocky bottoms and seagrass meadows (Guidetti 2000). Serranus scriba feeds on small fish and invertebrates such as crustaceans (Fasola et al. 1997) and is a simultaneous hermaphrodite (Fischer \& Petersen 1987). This species is included in the FAO catalogue of species of interest to fisheries in the Eastern Central Atlantic and in the Mediterranean and the Black Sea (Tortonese 1986, Bauchot 1987). S. scriba has been used as bioindicator of marine pollution (Roméo et al. 1999) and for monitoring temperate MPA effects (Francour 2000). In the Balearic Islands (NW Mediterranean), S. scriba is one of the most frequently targeted species for recreational boat anglers (Morales-Nin et al. 2005). Recent studies have used S. scriba to assess the impacts of recreational fisheries (Cardona et al. 2007, Alós 2008). Thus, information on movements of $S$. scriba is relevant for the management of recreational fisheries.
In this study, we used acoustic telemetry to examine the short-term movement patterns of a small temperate fish, the painted comber Serranus scriba. Specifically, the aims of the study were: (1) to quantify the home range and short-term movements of $S$. scriba; (2) to determine short-term residence; and (3) to determine the existence of diel patterns.

\section{MATERIALS AND METHODS}

Study site. The study was carried out between July 2007 and February 2008 at Palma Bay Marine Reserve (PBMR), Mallorca Island (NW Mediterranean). PBMR protects an open water area that extends between the shoreline and the $30 \mathrm{~m}$ isobath. This MPA is zoned into 2 management areas with different levels of protection: (1) the Integral Zone $\left(\sim 2 \mathrm{~km}^{2}\right)$, where all fishing activity is prohibited; and (2) the Buffer Zone $\left(\sim 24 \mathrm{~km}^{2}\right)$, where both artisanal and recreational fisheries are permitted, with some management regulations (i.e. daily bag limits, minimum hook size, and temporal closures). Environmental parameters in the MPA were monitored using an oceanographic buoy from the Mediterranean Institute of Advanced Studies (IMEDEA). The monitoring area in the present study was placed in the zone that encompasses both the Integral and Buffer zones, which is mainly dominated by seagrass meadows of Posidonia oceanica (Fig. 1).

Acoustic monitoring system. We used a fixed array of acoustic monitoring stations (Sonotronics, SUR-1) to track the movement of Serranus scriba. This system used small multifrequency, omnidirectional receivers, that measured and recorded the interval period between successive pings from individual transmitters. We used cylindrical ultrasonic transmitters (Sonotronics, PT-3: $19 \mathrm{~mm}$ in length, $7.8 \mathrm{~mm}$ in diameter, $1 \mathrm{~g}$ in water, $21 \mathrm{~d}$ lifetime). Each transmitter emitted a continuous acoustic signal with a unique combination of frequency (ranging between 69 and $83 \mathrm{kHz}$ ) and interval periods between pulses (ranging between 860 and $1250 \mathrm{~ms}$ ), to allow for the identification of individual fish. Transmitters were turned on for $24 \mathrm{~h} \mathrm{~d}^{-1}$, except 4 transmitters that were programmed to run intermittently to yield an active period of $12 \mathrm{~h} \mathrm{~d}^{-1}$ in order to increase the lifetime to approximately $35 \mathrm{~d}$. Those transmitters ran their set of pulses twice, and then added a period of silence for the same amount of time. Each successful signal detected by a receiver was recorded as a unique register with information regarding the date, time, frequency and interval period.

Receiver deployment. In July 2007, we deployed 25 receivers within the study site, approximately $450 \mathrm{~m}$ from each other, covering a monitoring area of approximately $5 \mathrm{~km}^{2}$ (Fig. 1). We oriented each receiver up- 


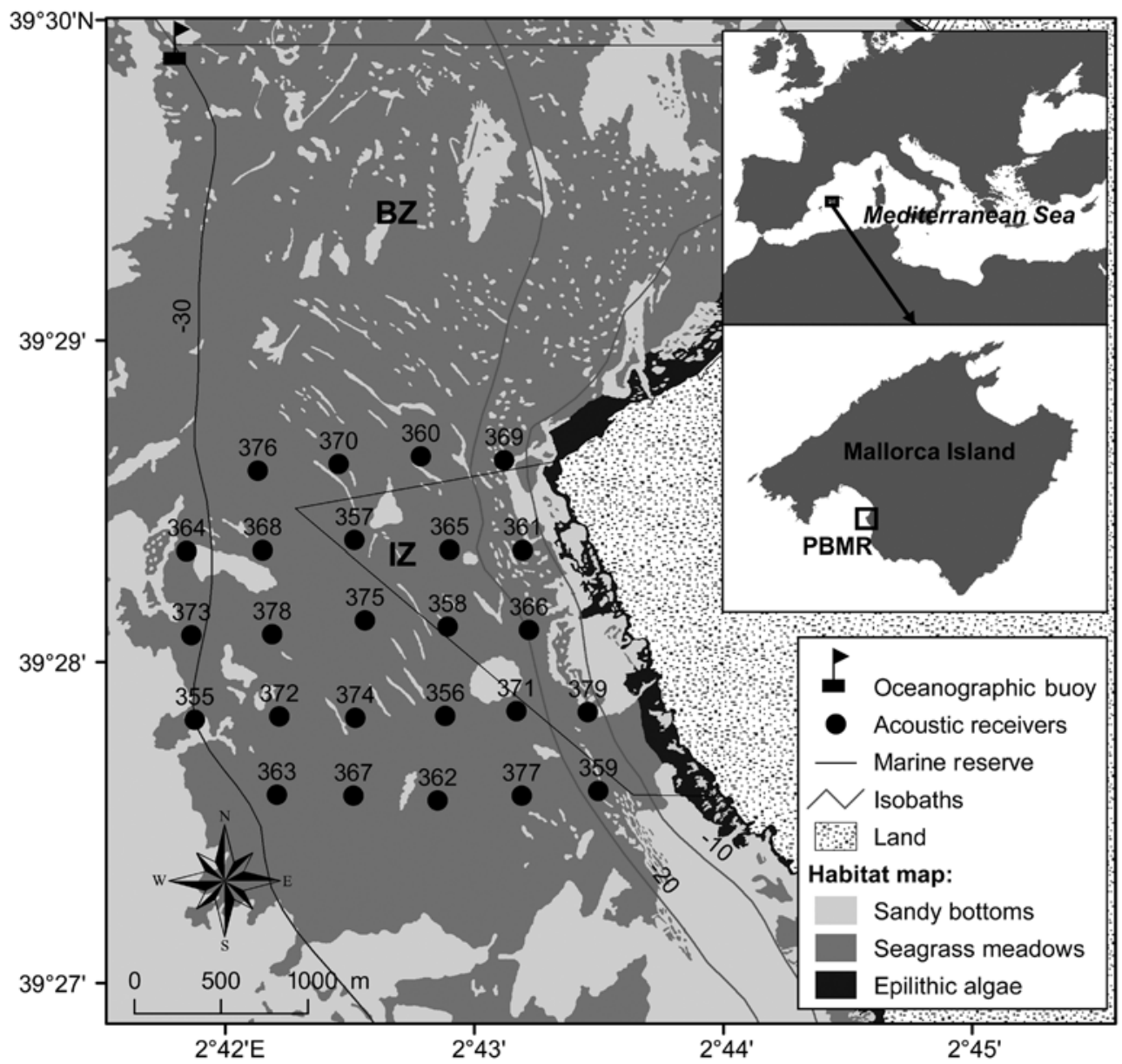

Fig. 1. Palma Bay Marine Reserve (PBMR). Habitat map showing the locations of the acoustic receivers. Marine reserve boundaries enclose the Integral Zone (IZ) and the Buffer Zone (BZ)

wards at 1 to $2 \mathrm{~m}$ from the bottom to optimize detections for demersal fishes and avoid thermocline effects. Receivers were placed at depths of 15 to $35 \mathrm{~m}$, where the range of detection was $250 \mathrm{~m}$ (D. March unpubl. data). The receiver array allowed fish to be monitored for most of the period that they were within the detection range of the receiver array. We retrieved receivers, downloaded data, cleaned off biofouling organisms and redeployed the receivers 3 times (in September 2007, November 2007 and February 2008).

Fish tagging. We released 15 tagged individuals of Serranus scriba from July 2007 to December 2007 (Table 1). Tagged fish were reproductively mature and were collected after the spawning season (Bauchot 1987). Fish were captured during the daytime within the study area with a hook and line using large $\mathrm{J}$ hooks. To avoid internal injuries from swim bladder expansion, fish were captured at depths between 10 and $25 \mathrm{~m}$ and, if necessary, were punctured with a hypodermic needle to release trapped gasses (Alós 2008). After capture, fish were transferred immediately to fresh seawater tanks following a procedure similar to that used for small fish (Jadot et al. 2006). Fish were anaesthetised with a $100 \mathrm{mg} \mathrm{l}^{-1}$ solution of tricaine methanosulfate (MS222). After being fully anaesthetized, they were weighed to the nearest $g$ and total length (TL) was measured to the nearest $1 \mathrm{~mm}$. Transmitters were surgically inserted into the peritoneal cavity and the incision was closed using synthetic absorbable sutures. Transmitters did not exceed $1.7 \%$ of the body weight of the fish. The surgery process took less $<5 \mathrm{~min}$. A preliminary evaluation of the surgical procedure using 'dummy' transmitters with 6 individuals revealed normal behaviour 8 to $10 \mathrm{~min}$ after surgery, full cicatrisation without transmitter loss after $6 \mathrm{wk}$, and $100 \%$ survival after 6 mo (Grau \& Palmer unpubl. data). Following full recovery in a seawater tank, fish were released in good condition in the middle of the array to guarantee initial detection.

Data analysis. We used a Microsoft Access database to store and manage detection data. We matched each recorded detection to a unique individual by the fre- 
quency and the interval period between pulses (using a tolerance of $5 \mathrm{~ms}$ : see Sonotronics Unique Pinger ID Algorithm. Accessed 26 May. www.sonotronics.com/ docs/PingerAlgorithm.pdf). We then filtered our data to remove potentially spurious detections. We defined spurious detections as any single transmitter code detection occurring alone within a $24 \mathrm{~h}$ period. We developed a decision tree diagram to formalize the process of fish selection for the different analyses, where we took into account: (1) the number of receivers detected, (2) the detection period, and (3) the results of both temporal and spatial analyses. All spatial and statistical analyses were performed with a custom program written in $\mathrm{R}$ ( $\mathrm{R}$ Foundation: www.rproject.org).

Residence time: We plotted daily presence histories to visually inspect the timeline of fish presence. We calculated the total period between the release date and the last detection (total period of detection: TP), as well as the number of days detected (DD). We used both types of data to calculate a residence index $\left(R_{I}\right)$, defined as the quotient between the DD and the TP. In contrast to Abecasis \& Erzini (2008), we estimated $R_{I}$ for each fish, rather than for each receiver, and used it as an alternative to determining the number of consecutive days of presence (Collins et al. 2007). We used a Pearson's correlation test to evaluate differences in TP, $\mathrm{DD}$ and $\mathrm{R}_{\mathrm{I}}$ with fish size.

Temporal patterns: Temporal patterns were analysed for fish that were detected for $5 \mathrm{~d}$ or more. We pooled the detections of all receivers into hourly bins for each fish, and visually inspected the data using chronograms. We then used the continuous wavelet transform (CWT) to identify periodicity patterns in Serranus scriba detection hourly bins. The CWT is a powerful tool for decomposing a time series into time-frequency space (Percival \& Walden 2000), which has been previously applied on data storage tags (Subbey et al. 2008). We computed the 2-dimensional wavelet spectrum and pointwise test (95\% significance level) using a Morlet wavelet with the SOWAS package in R (Maraun et al. 2007). Wavelet coefficient values were normalized such that the highest spectral power equaled one. Finally, we investigated diel patterns by binning hourly detection data for each individual into daily phases (day/night) and then comparing mean detections in each phase bin. We defined each phase using sunrise and sunset data obtained from the U.S. Naval Observatory (Astronomical Applications Department, accessed 26 May: http://aa.usno.navy. $\mathrm{mil} /$ ). Diel data were non-normally distributed and could not be transformed adequately. We used a nonparametric Mann-Whitney $U$-test to evaluate the hypothesis that the number of detections was different between day and night.
Spatial patterns: Spatial movement patterns were analysed for fish that were detected at more than 1 receiver. We used the Nadaraya-Watson normal kernel estimator (sm package in $R_{i}$ Bowman \& Azzalini 1997) to calculate position estimates, or centre of activity (COA) locations, for monitored fish every $60 \mathrm{~min}$ (see Simpfendorfer et al. 2002, Hedger et al. 2008). Processed data were used for all of the following analyses.

For comparison, we estimated the home range over the total period of detection using 2 methods: (1) Minimum convex polygons (MCP) based on $100 \%$ of the positions (MCP 100); and (2) bivariate normal fixed kernel utilization distributions (KUD; 95 and 50\% KUD). The MCP provided information regarding the extent of an animal's range over a given period, while KUDs provided information regarding the use of space within that range including core area (50\% KUD) and home range $(95 \% \mathrm{KUD})$. We calculated KUDs over a grid of $15 \times 15 \mathrm{~m}$ resolution using the adehabitat package in $\mathrm{R}$ (Calenge 2006). We selected a kernel bandwidth of $250 \mathrm{~m}$, corresponding to the detection range of the transmitter. To determine whether the home range size was related to residence time or fish size, we compared total MCP and KUDs to the total period of detection (TP) and fish size (TL) using the Pearson's correlation test.

We investigated changes in home range over time based on $95 \%$ KUD. Observation-area curves were calculated by plotting cumulative home ranges over a period of days. We assessed when an asymptote was reached as the point when the percent change of the accumulated area was $<5 \%$ (Rechisky \& Wetherbee 2003). For every fish, the percent change for each tracking day was calculated as:

$$
\% \text { change }=\left[\left(A_{t}-A_{t-1}\right) / A_{t}\right] \times 100
$$

where $A_{t}$ is the $95 \%$ KUD area at day $t$, and $A_{t-1}$ is the $95 \%$ KUD area at the previous day $(t-1)$. We only reported total home range estimates for fish for which the home range approached an asymptote, as recommended by Laver \& Kelly (2008).

We calculated 2 measurements of site fidelity: (1) the linearity index $\left(\mathrm{L}_{\mathrm{i}}\right)$; and $(2)$ the index of reuse $\left(\mathrm{IOR}_{i}\right.$ Rechisky \& Wetherbee 2003). $\mathrm{L}_{\mathrm{i}}$ was calculated as follows:

$$
\mathrm{L}_{\mathrm{i}}=\left(F_{\mathrm{n}}-F_{1}\right) / D
$$

where $F_{\mathrm{n}}-F_{1}$ is the distance between the first and last COA, and $D$ is the total distance travelled. Fish with nomadic behaviour should have $\mathrm{L}_{\mathrm{i}}$ values close to 1 , while fish with strong site fidelity should have an $\mathrm{L}_{\mathrm{i}}$ value approaching 0 . The IOR is calculated as:

$$
\operatorname{IOR}=\left[\mathrm{OV}\left(A_{1}, A_{2}\right)\right] /\left[\mathrm{UN}\left(A_{1}, A_{2}\right)\right]
$$

where $\left.\operatorname{COV}\left(A_{1}, A_{2}\right)\right]$ is the area of overlap between 2 activity spaces (i.e. daily 50 and $95 \%$ KUD areas), and 
[UN $\left.\left(A_{1}, A_{2}\right)\right]$ is the area of union of both activity spaces. An IOR of 1 indicates a complete overlap of activity space (site fidelity), while an IOR of 0 indicates nonoverlap of activity space (nomadic behaviour).

To test for diel differences in home range size and home range shift for all fishes, we calculated: (1) daytime and nighttime KUDs on a daily basis; and (2) the IOR between total daytime and nighttime activity spaces. Paired $t$-tests were used to detect differences between day and night on the home range patterns for each fish.

\section{RESULTS}

Between June 2007 and January 2008, 16 (64\%) of the 25 receivers detected all of the 15 released fish. Fish detections are summarized in Table 1. The total number of detections ranged from 41 to 314 detections for fish with tags programmed to run for $12 \mathrm{~h} \mathrm{~d}^{-1}$, while for tags that run $24 \mathrm{~h} \mathrm{~d}^{-1}$, the number of detections ranged from 107 to 5560 .

The generated decision tree diagram is presented in Fig. 2. One tagged fish (\#106) was excluded from all analyses, as it was only detected by 1 receiver on only a single day and registered just 41 detections. Battery failure, death, capture by fishermen or predation by other animals could be the reason for that pattern. Two more fish (\#200 and \#160) were excluded from temporal analyses as they were detected for a period of $<5 d$; 3 other fish (\#3, \#5 and \#18) were excluded from spatial analysis because they were detected by only 1 receiver.

\section{Residence time}

Short-time residence differed among tagged fish (Fig. 3). Some fish were not detected beyond a few days post-release, while others remained within the

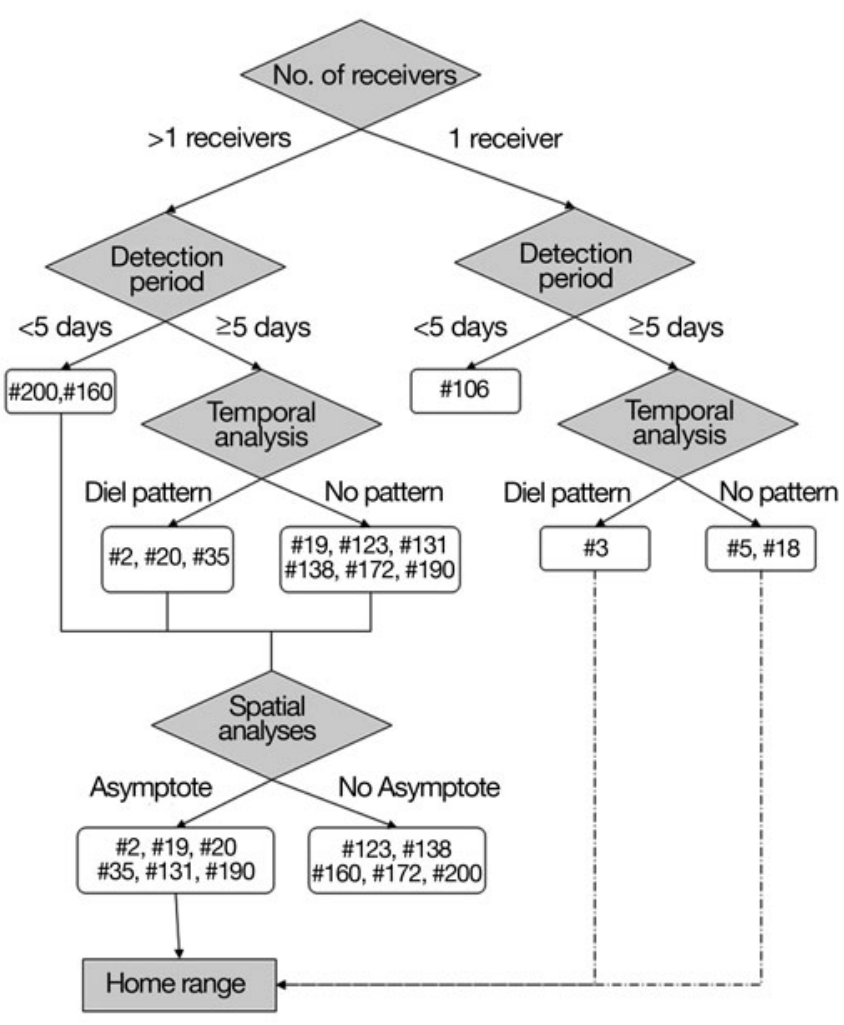

Fig. 2. Serranus scriba. Decision tree diagram used to select fish for reporting home range sizes

Table 1. Serranus scriba. Summary of the monitoring data for the 15 tagged fish. TL = total length; TP = total period of detection; $\mathrm{DD}=$ number of days detected; and $\mathrm{R}_{\mathrm{I}}=$ residence index

\begin{tabular}{|c|c|c|c|c|c|c|c|c|}
\hline $\begin{array}{l}\text { Fish } \\
\text { code }\end{array}$ & $\begin{array}{c}\mathrm{TL} \\
(\mathrm{mm})\end{array}$ & $\begin{array}{l}\text { Weight } \\
\text { (g) }\end{array}$ & $\begin{array}{l}\text { Release date } \\
\text { (yy/mm/dd) }\end{array}$ & $\mathrm{TP}(\mathrm{d})$ & $\mathrm{DD}(\mathrm{d})$ & $\mathrm{R}_{\mathrm{I}}$ & $\begin{array}{c}\text { Total } \\
\text { detections }\end{array}$ & $\begin{array}{l}\text { No. of } \\
\text { receivers }\end{array}$ \\
\hline 2 & 184 & 62 & 07/09/17 & 27 & 26 & 0.96 & 4475 & 9 \\
\hline 3 & 169 & 66 & 07/09/26 & 29 & 29 & 1.00 & 5560 & 1 \\
\hline 5 & 184 & 83 & 07/09/17 & 6 & 6 & 1.00 & 1179 & 1 \\
\hline 18 & 173 & 61 & 07/09/17 & 36 & 35 & 0.97 & 2242 & 1 \\
\hline 19 & 172 & 64 & $07 / 09 / 26$ & 5 & 5 & 1.00 & 504 & 4 \\
\hline 20 & 169 & 66 & 07/09/26 & 30 & 30 & 1.00 & 1037 & 4 \\
\hline $35^{\mathrm{a}}$ & 183 & 81 & $07 / 12 / 17$ & 9 & 9 & 1.00 & 168 & 4 \\
\hline $106^{\mathrm{a}}$ & 193 & 89 & $07 / 12 / 17$ & 1 & 1 & 1.00 & 41 & 1 \\
\hline 123 & 179 & 69 & $07 / 07 / 26$ & 5 & 5 & 1.00 & 2930 & 8 \\
\hline 131 & 180 & 70 & $07 / 08 / 30$ & 9 & 9 & 1.00 & 2580 & 7 \\
\hline $138^{\mathrm{a}}$ & 172 & 74 & $07 / 12 / 14$ & 7 & 7 & 1.00 & 201 & 4 \\
\hline 160 & 217 & 136 & $07 / 12 / 17$ & 2 & 2 & 1.00 & 107 & 4 \\
\hline $172^{\mathrm{a}}$ & 197 & 93 & $07 / 12 / 14$ & 27 & 8 & 0.30 & 314 & 3 \\
\hline 190 & 177 & 73 & $07 / 12 / 17$ & 5 & 5 & 1.00 & 192 & 3 \\
\hline 200 & 175 & 74 & 07/12/14 & 4 & 4 & 1.00 & 466 & 5 \\
\hline
\end{tabular}


study area for a longer time period. Two fish were initially released in July and August, whereas the others were released in 2 groups. The first group contained 6 fish and was released in September, while the second group contained 7 fish and was released in December. Total periods of fish presence ranged between 1 to $36 \mathrm{~d}$ (Table 1). The mean total monitoring period for all Serranus scriba was $13 \mathrm{~d}$. The $\mathrm{R}_{\mathrm{I}}$ scores resulted in high values $(0.95 \pm 0.18$, mean $\pm \mathrm{SD}$ ), indicating a continuous presence of fishes through the total period of detections within the monitoring area. However, fish \#172 presented a high intermittent detection pattern, resulting in the lowest $R_{I}(0.3)$. This pattern was demonstrated after the fish moved out from the monitoring area $4 \mathrm{~d}$ after the release date and reappeared intermittently. There were non-significant correlations between fish size and residence time measures $\left(\mathrm{r}^{2}=-0.25\right.$ for $\mathrm{TP}, \mathrm{n}=$ $14, \mathrm{p}=0.327 ; \mathrm{r}^{2}=-0.42$ for $\mathrm{DD}, \mathrm{n}=14, \mathrm{p}=0.137 ; \mathrm{r}^{2}=$ -0.36 for $\left.\mathrm{R}_{\mathrm{I}}, \mathrm{n}=14, \mathrm{p}=0.203\right)$.

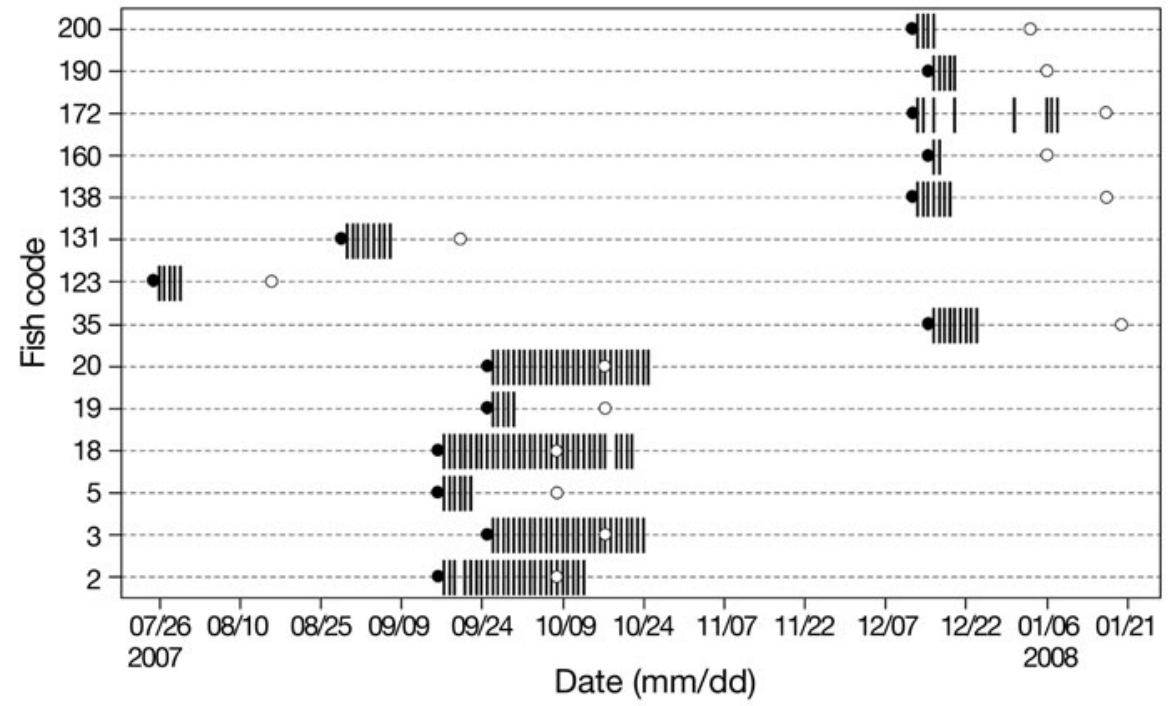

Fig. 3. Serranus scriba. Abacus plot of daily presence (vertical lines = dates detected) of tagged individuals within the monitoring area between July 2007 and January 2008. (•) Transmitter deployment dates; (O) predicted transmitter death dates

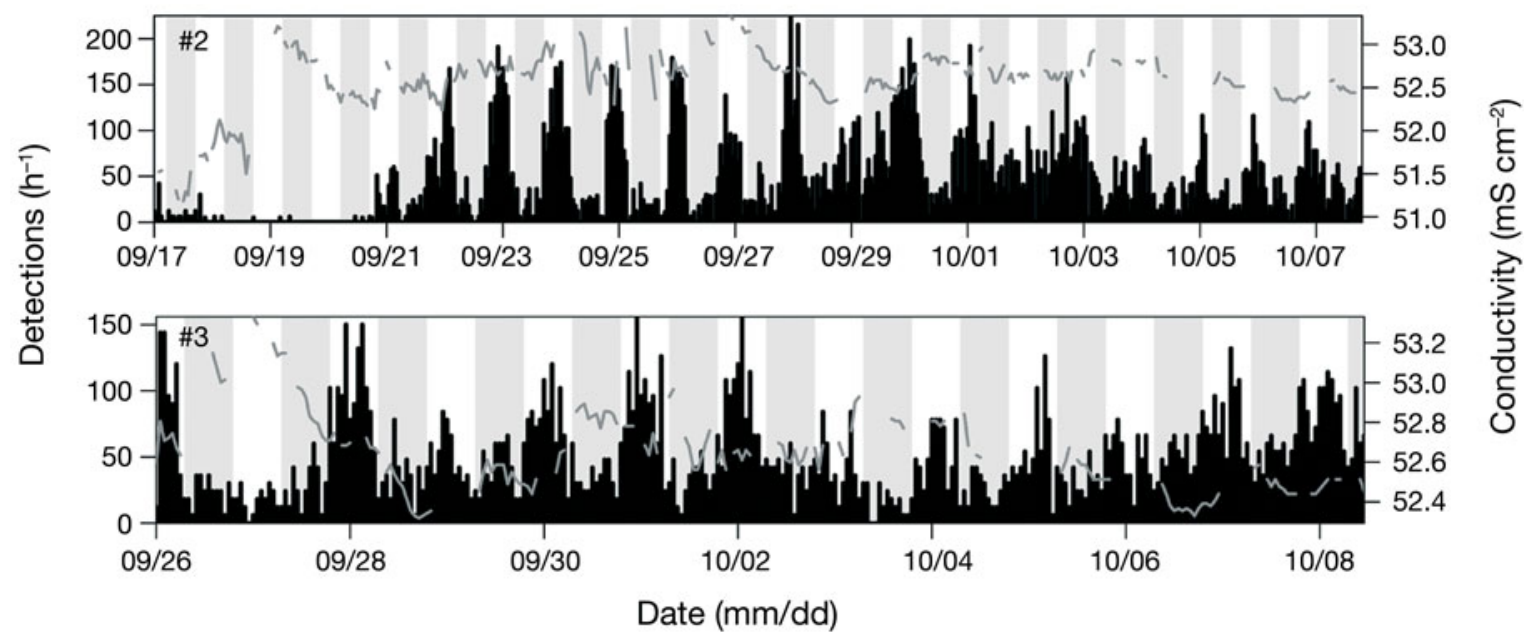

Fig. 4. Serranus scriba. Time plots of hourly detection bins (vertical black histograms) and water conductivity (gray line) of 2 individuals in 2007 . Vertical stripes of shading show nighttime periods. An approximately $24 \mathrm{~h}$ pattern oscillation is evident in fish \#2 and \#3, with a higher number of detections occurring during daytime 


\section{Temporal patterns}

Chronograms of hourly detections revealed a diel pattern for some fish, with a higher number of detections occurring during the daytime than at night (Fig. 4). However, this pattern was not constant throughout the detection period and was not evident for all fish. Oceanographic features such as water conductivity did not show a correlation with the number of detections (Fig. 4). The use of CWT allowed the identification of periodicities in the time series of detection data. Of the 12 fish analysed, 4 $(33.3 \%)$ presented clear periodicities of $24 \mathrm{~h}$ in their wavelet spectrograms (Fig. 5). Fish \#2 and \#20 also presented significant patches in the $12 \mathrm{~h}$ scale within a more localized timeframe, which could be the result of a crepuscular cycle or an increment of the number of detections at midnight. In addition, fish \#20 also showed a significant patch at the $48 \mathrm{~h}$ scale. As the $48 \mathrm{~h}$ patch occurred at the same time than the $24 \mathrm{~h}$ patches, it was likely to be the second harmonic of the $24 \mathrm{~h}$ scale. All 12 fish presented a higher mean number of detections during the daytime than at night (Table 2). However, only the 4 fish with $24 \mathrm{~h}$ periodicities identified by CWT presented significant differences (Mann-Whitney $U$-test, p < 0.05: Table 2).

\section{Movement patterns}

Asymptote analysis based on observation-area curves are presented in Fig. 6 a,b. Five fish (\#123, \#138, \#160, \#172 and \#200) increased their home ranges without reaching an asymptote (Table 3 ). Their estimated paths indicated that those fish moved toward the boundaries of the monitoring array over a short period. After that period, the fish were no longer

Table 2. Serranus scriba. Temporal analysis of 12 tagged fish. $W$ values correspond to a Mann-Whitney $U$-test. ${ }^{*} p<0.05$; ${ }^{* *} \mathrm{p}<0.01$; and ${ }^{\mathrm{ns}}$ not significant

\begin{tabular}{|lccc|}
\hline $\begin{array}{l}\text { Fish } \\
\text { code }\end{array}$ & $\begin{array}{c}\text { Daytime } \\
\text { detections } \\
\text { (mean } \pm \text { SD) }\end{array}$ & $\begin{array}{c}\text { Nighttime } \\
\text { detections } \\
\text { (mean } \pm \text { SD) }\end{array}$ & $W$ \\
\hline 2 & $118 \pm 79$ & $48 \pm 38$ & $159.5^{* *}$ \\
3 & $119 \pm 61$ & $73 \pm 37$ & $173.0^{* *}$ \\
5 & $105 \pm 54$ & $91 \pm 51$ & $21.0^{\text {ns }}$ \\
18 & $33 \pm 36$ & $31 \pm 25$ & $644.5^{\text {ns }}$ \\
19 & $64 \pm 59$ & $36 \pm 21$ & $8.5^{\text {ns }}$ \\
20 & $23 \pm 19$ & $11 \pm 8$ & $205.0^{* *}$ \\
35 & $16 \pm 13$ & $5 \pm 4$ & $8.0^{*}$ \\
123 & $385 \pm 219$ & $201 \pm 185$ & $8.0^{\text {ns }}$ \\
131 & $155 \pm 66$ & $132 \pm 80$ & $41.0^{\text {ns }}$ \\
138 & $19 \pm 21$ & $10 \pm 15$ & $15.5^{\text {ns }}$ \\
172 & $24 \pm 38$ & $11 \pm 18$ & $22.5^{\text {ns }}$ \\
190 & $25 \pm 23$ & $13 \pm 26$ & $4.0^{\text {ns }}$ \\
\hline
\end{tabular}
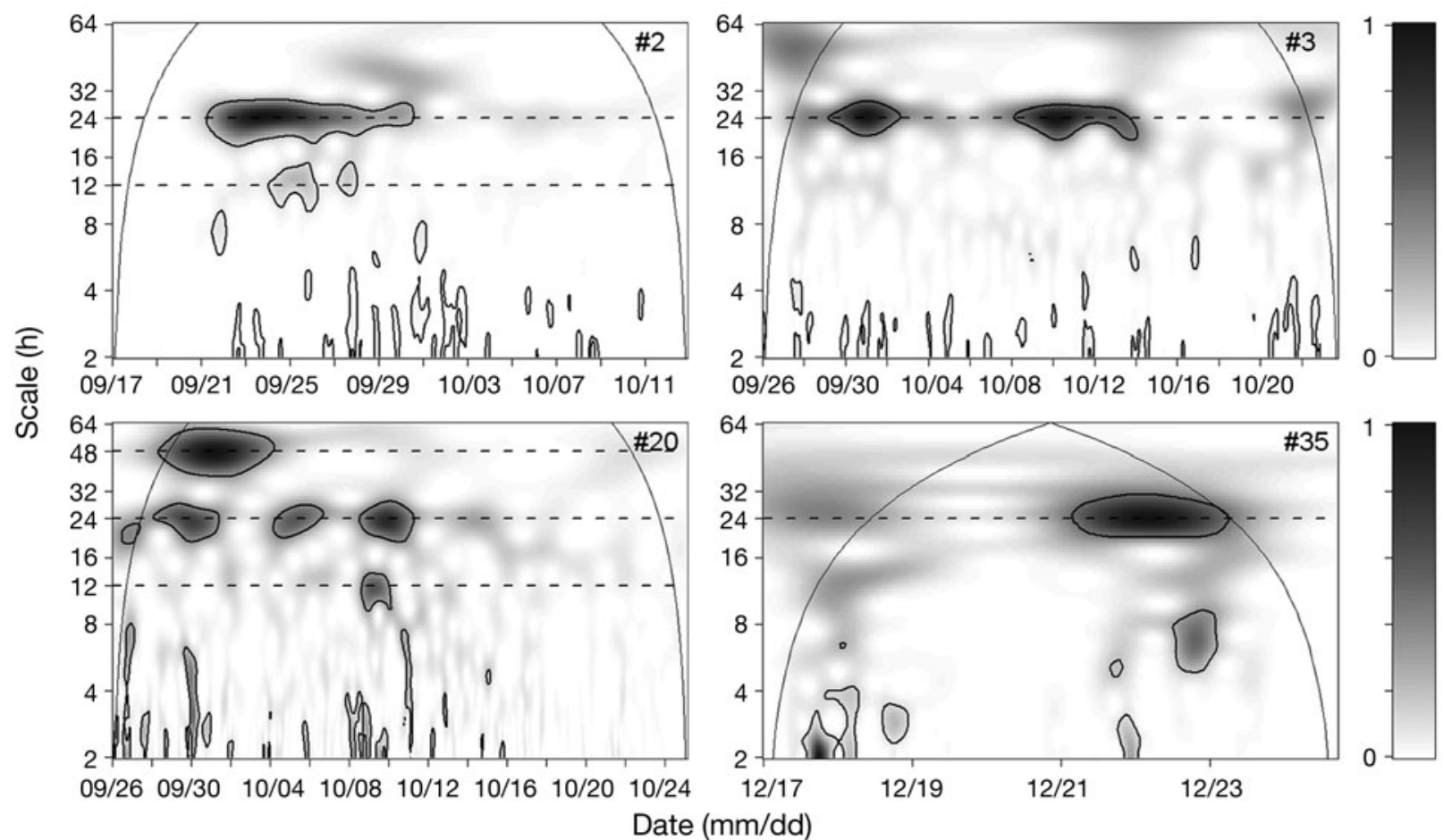

Fig. 5. Serranus scriba. Wavelet sample spectrums of fish \#2, \#3, \#20 and \#35 using a Morlet wavelet with normalized coefficients. Horizontal dashed line represents the $12 \mathrm{~h}, 24 \mathrm{~h}$ and $48 \mathrm{~h}$ scales. Continuous thin lines represent the cone of influence (COI). Values outside the COI should not be interpreted due to edge effects. Thick contours represent the $95 \%$ confidence level 


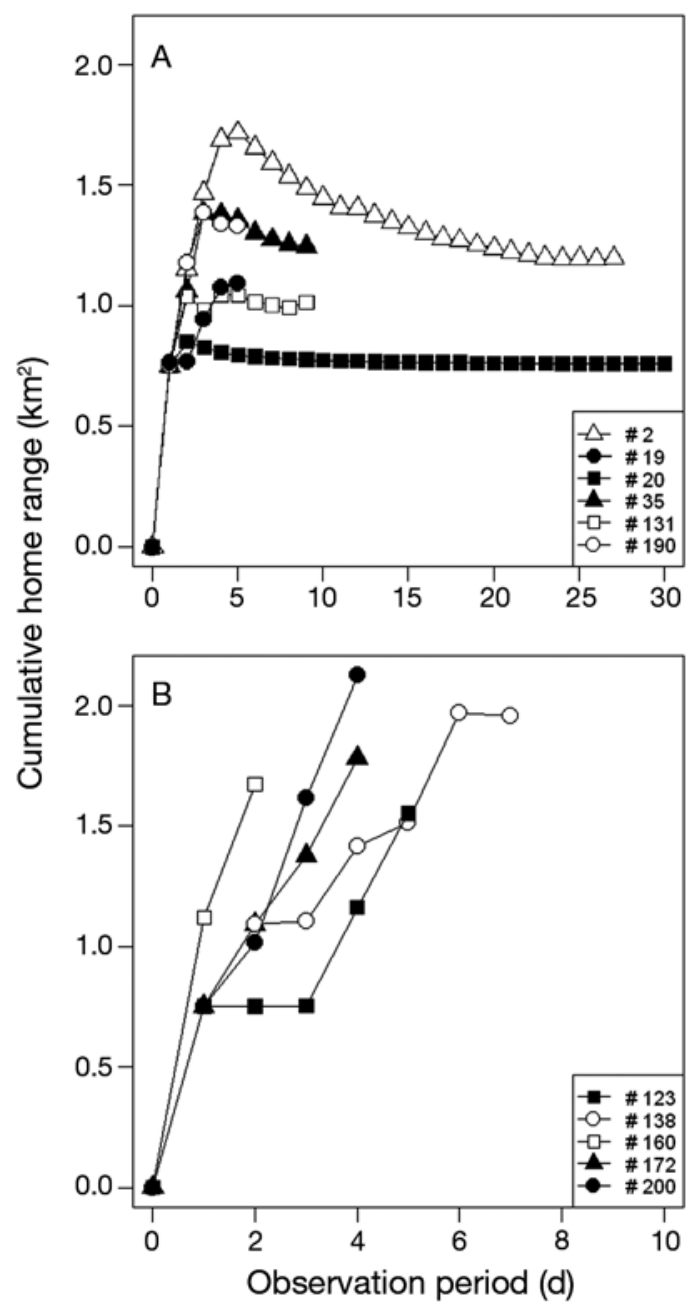

Fig. 6. Serranus scriba. Observation-area curves for 11 fish tracked in Palma Bay. (A) Individuals whose 95\% kernel utilization distribution (KUD) reaches an asymptote, indicating that activity space increased little with additional tracking time; and (B) individuals whose 95\% KUD increases $>5 \%$ between consecutive tracking days and does not reach an asymptote

detected with the exception of fish \#172, which was intermittently detected by the receivers located at the boundaries. The other 6 fish (\#2, \#19, \#20, \#35, \#190, \#131) also increased their home ranges during the first days but then stabilized their home range size, reaching an asymptote based on the $5 \%$ change criteria. The period for stabilization ranged between 3 and $6 \mathrm{~d}$ (Table 3). After that period, home range size was stable, except for fish \#2 and \#19, whose home range sizes decreased due to the repeated use of their activity space (Fig. 6a). No significant differences were found between fish groups (with and without asymptote) and fish TL ( $t$-test, $d f=6, p=0.579$ ).

Home range sizes (95\% KUD and MCP) and core areas $(50 \% \mathrm{KUD})$, are presented in Table 3, while some examples are plotted in Fig. 7. We did not report home range estimates for fish that did not reach an asymptote. The total home range obtained with $95 \%$ KUD ranged between 0.760 and $1.333 \mathrm{~km}^{2}$, with a mean size of $1.108 \mathrm{~km}^{2}$; total home range obtained with MCP ranged between 0.102 and $0.671 \mathrm{~km}^{2}$, with a mean size of $0.248 \mathrm{~km}^{2}$. The total home range size estimated with MCP was significantly smaller than that obtained with $95 \%$ KUD ( $t$-test paired for means, $t=$ 8.346, $\mathrm{df}=5, \mathrm{p}<0.001)$. The core area ranged between 0.175 and $0.294 \mathrm{~km}^{2}$, with a mean size of $0.241 \mathrm{~km}^{2}$. Total home range areas did not exhibit a significant relationship with fish TL $\left(\mathrm{r}^{2}=0.71\right.$ for $\mathrm{MCP}, \mathrm{n}=6, \mathrm{p}=$ $0.116 ; \mathrm{r}^{2}=0.66$ for $95 \% \mathrm{KUD}, \mathrm{n}=6, \mathrm{p}=0.155$ ) or with the track duration $\left(\mathrm{r}^{2}=0.46\right.$ for $\mathrm{MCP}, \mathrm{n}=6, \mathrm{p}=0.363$; $\mathrm{r}^{2}=-0.57$ for $95 \%$ KUD, $\mathrm{n}=6, \mathrm{p}=0.241$ ).

$\mathrm{L}_{\mathrm{i}}$ values were low for most of the fish, but were highly variable, with a mean $( \pm \mathrm{SD})$ of $0.326 \pm 0.308$ (Table 3). Higher values were found in fish whose home range did not reach an asymptote $(0.582 \pm 0.252$, mean $\pm \mathrm{SD}$ ), indicating that movements tended to be unidirectional. Lower values corresponded to fishes that reached an asymptote $(0.112 \pm 0.135$, mean $\pm S D)$, indicating little movements from the area with a repeated use of the activity space. We compared $\mathrm{L}_{\mathrm{i}}$ values between fish with and without asymptotes in their home ranges and found significant differences ( $t$-test, $\mathrm{df}=6, \mathrm{p}=0.010)$. IOR values were higher (Table 3 ), and negatively correlated with $\operatorname{Li}\left(\mathrm{r}^{2}=-0.60, \mathrm{n}=11, \mathrm{p}=\right.$ 0.053). IOR values based on a $95 \%$ KUD daily shift were higher $(0.81 \pm 0.26$, mean $\pm \mathrm{SD})$, than those based on a $50 \% \operatorname{KUD}(0.76 \pm 0.33$, mean $\pm \mathrm{SD})$.

Tracked fish did not exhibit any detectable diel pattern in home range size or home range shift. There were no differences for any fish between day and night based on both $95 \%$ KUD and $50 \%$ KUD ( $t$-test, p > 0.05). When comparing total home range areas during the day and night for each fish, IOR values for $95 \%$ KUD were higher $(0.76 \pm 0.21$, mean $\pm \mathrm{SD})$ than for $50 \% \operatorname{KUD}(0.58 \pm 0.37$, mean \pm SD $)$.

\section{DISCUSSION}

\section{Residency and site fidelity}

Tracked fish were detected within the monitoring area for varying lengths of time, and usually through consecutive days. This suggests a continuous use of the monitoring area through the detected period. Only one fish (\#172) presented a transient use of the study site. As intermittent detections of this fish were received by a monitoring station located in the boundaries of the array, the loss of contact with this fish could be the result of movement out of the study area. Five of the 15 tagged fish were monitored for more than $25 \mathrm{~d}$, sug- 
Table 3. Serranus scriba. Movement statistics-MCP: minimum convex polygon; KUD: kernel utilization distribution; IOR: index of reuse. IOR values are estimated with $95 \%$ KUD. Asymptote values correspond to the period used for each fish to reach an asymptote in their accumulated home range area (95\% KUD) based on the $5 \%$ change criteria. Total home range estimates were not reported for fish that did not reach an asymptote

\begin{tabular}{|c|c|c|c|c|c|c|c|c|c|}
\hline $\begin{array}{l}\text { Fish } \\
\text { code }\end{array}$ & $\begin{array}{l}\mathrm{MCP} \\
\left(\mathrm{km}^{2}\right)\end{array}$ & $\begin{array}{c}95 \% \text { KUD } \\
\left(\mathrm{km}^{2}\right)\end{array}$ & $\begin{array}{c}50 \% \text { KUD } \\
\left(\mathrm{km}^{2}\right)\end{array}$ & $\begin{array}{l}\text { Asymptote } \\
\text { (d) }\end{array}$ & $\mathrm{L}_{\mathrm{i}}$ & $\begin{array}{c}\text { Daily IOR } \\
(\text { mean } \pm \text { SD) }\end{array}$ & $\begin{array}{l}\text { Day-Night IOR } \\
(\text { mean } \pm \text { SD) }\end{array}$ & $\begin{array}{c}95 \% \text { KUD } \\
\text { daytime }\left(\mathrm{km}^{2}\right)\end{array}$ & $\begin{array}{c}95 \% \text { KUD } \\
\text { nighttime }\left(\mathrm{km}^{2}\right)\end{array}$ \\
\hline 2 & 0.671 & 1.197 & 0.215 & 5 & 0.015 & $0.81 \pm 0.19$ & 0.95 & 1.204 & 1.189 \\
\hline 19 & 0.116 & 1.092 & 0.267 & 5 & 0.177 & $0.76 \pm 0.21$ & 0.76 & 0.955 & 1.130 \\
\hline 20 & 0.102 & 0.760 & 0.175 & 3 & 0.000 & $0.99 \pm 0.04$ & 0.99 & 0.761 & 0.759 \\
\hline 35 & 0.214 & 1.248 & 0.273 & 4 & 0.143 & $0.84 \pm 0.25$ & 0.82 & 1.100 & 1.320 \\
\hline 123 & - & - & - & - & 0.311 & $0.69 \pm 0.36$ & 0.74 & 1.528 & 1.391 \\
\hline 131 & 0.248 & 1.015 & 0.223 & 5 & 0.000 & $0.74 \pm 0.11$ & 0.86 & 1.064 & 0.938 \\
\hline 138 & - & - & - & - & 0.643 & $0.59 \pm 0.37$ & 0.77 & 1.902 & 1.827 \\
\hline 160 & - & - & - & - & 0.795 & $0.16^{\mathrm{a}}$ & 0.22 & 1.498 & 1.341 \\
\hline 172 & - & - & - & - & 0.839 & $0.78 \pm 0.42$ & 0.89 & 1.678 & 1.774 \\
\hline 190 & 0.135 & 1.333 & 0.294 & 4 & 0.340 & $0.61 \pm 0.18$ & 0.72 & 1.141 & 1.487 \\
\hline 200 & - & - & - & - & 0.325 & $0.38 \pm 0.29$ & 0.68 & 2.102 & 1.896 \\
\hline
\end{tabular}
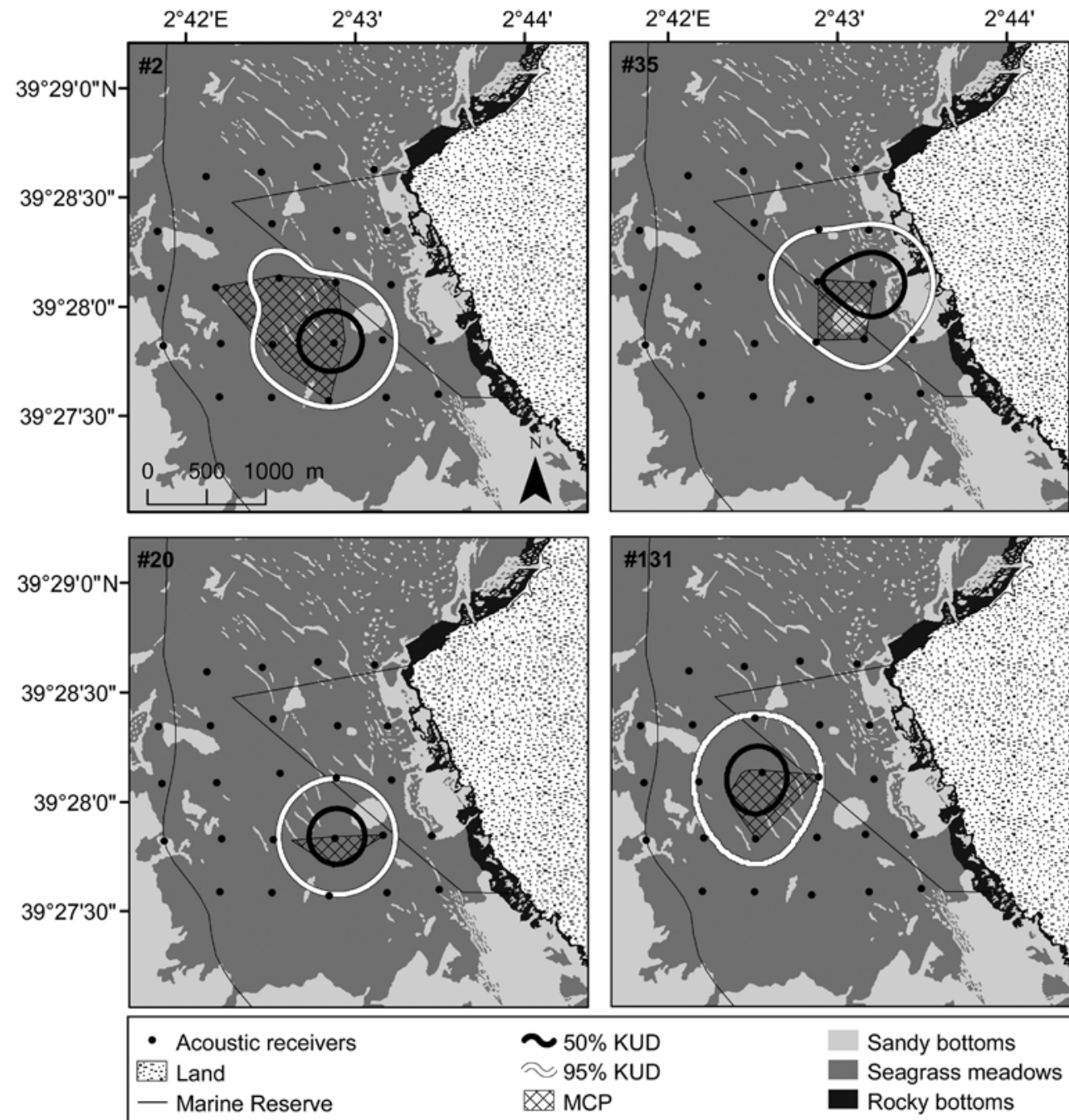

Fig.7. Serranus scriba. Total home range areas (MCP and $95 \%$ KUD) and core areas (50\% KUD) for 4 individuals tracked within the monitoring area. See Table 3 for abbreviations 
gesting a consistent pattern of residence. However, the majority of tracked fish were monitored for shorter periods due to the loss of their detections. In other studies conducted with bigger Serranids and long-life transmitters or conventional external tags, longer time residence periods were reported for Plectropomus leopardus (202 d, Zeller 1997), Epinephelus guttatus (54 to 143 d, Shapiro et al. 1994), Epinephelus tauvina (5 to 105 d, Kaunda-Arara \& Rose 2004) and Paralabrax clathratus (3 yr, Lowe et al. 2003). The limitation of battery lifetime is an important factor when considering residence time. As in our study, this factor is relevant when working with small fish as battery lifetime is directly proportional to transmitter size. Thus, in our study, we could only evaluate short-time residence due to the small size of Serranus scriba.

\section{Diel patterns}

Results suggest diel patterns for some individuals of Serranus scriba, though this pattern was not observed in all fishes. Constant diel patterns for all fish were reported by other authors (Topping et al. 2005, Jorgensen et al. 2006), though intraspecific variability was also found in Sarpa salpa (Jadot et al. 2006). The diel pattern in the number of detections of acoustic transmitters could be influenced by several factors. Based on temporal series data from the oceanographic buoy, we excluded the effect of diel variability of different water parameters such as temperature, salinity or conductivity that could affect transmission attenuation. Other authors have detected diel shifts in the home range to different habitats (Jadot et al. 2006) and found a negative relationship between detection frequency and rate of movement (Topping et al. 2006), or that higher number of detections during the day were related to periods of activity (Zeller 1997). In our study however, we did not detect diel differences in horizontal movement patterns. A possible explanation for the diel frequency of detections could be based on the behaviour of $S$. scriba in relation with the structure of the dominant habitat type, Posidonia oceanica meadows. Seagrasses have a significant effect on sound propagation due to their lacunar air system, which could produce high levels of transmission loss (MiksisOlds \& Miller 2006). A comparative test between transmitters positioned inside and above $P$. oceanica indicated that tags inside seagrass canopy could decrease the number of detections by up to $80 \%$ (D. March unpubl. data). Therefore, if S. scriba hid under the canopy of the seagrass during the night, the number of detected signals at night should be lower. This diel pattern could be supported by different studies that reported: (1) significantly lower abundance estimates of S. scriba during the night (Reñones et al. 1995, Azzurro et al. 2007), and (2) a diurnal feeding activity of a similar species, Serranus atricauda (Morato et al. 2000). These findings would suggest that S. scriba could exhibit a differential behaviour with a high activity period during the day (i.e. swimming and predating over the seagrass), and a resting period during the night (i.e. due to food partitioning with nocturnal competitors such as Scorpaena porcus: Arculeo et al. 1993). Although this explanation is plausible, the intraspecific variability and the short temporal duration of this study makes it difficult to identify concrete causal mechanisms. Further research using laboratory-oriented experiments (Reebs 2002) could be used to examine the factors associated with such plasticity.

The implications of diel patterns are also important in relation to the criteria used to include or discard fishes for analyses (Fig. 2). It is common to consider as dead those fish that are continuously detected at a single receiver (e.g. Taylor et al. 2006). In our study, fish \#3 was continuously detected by only 1 receiver over $29 \mathrm{~d}$, but exhibited a diel pattern in the number of detections in contrast with individuals \#5 and \#18. Based on our interpretation of a differential behaviour in relation with seagrass structure, it would be possible that fish \#3 could be alive. This fish could be exhibiting a similar behaviour to the other individuals with diel patterns that were detected at $>1$ receiver, but moving within a more reduced activity space.

\section{Movement patterns}

Our findings support several common assumptions about Serranus scriba behaviour. Based on direct observations, S. scriba has been described as a sedentary and territorial species, suggesting a limited dispersal capacity (Bauchot 1987, Harmelin 1987). In addition, our findings revealed intraspecific variability. Serranus scriba exhibited both resident and mobile behaviour. Resident fish presented a higher site fidelity in a smaller area without daily shifts, while non-resident fish tended to exhibit more linear movements. Indices of reuse were high, although the available area for fish was extensive.

Home range size estimates are highly dependent upon the method used. Minimum convex polygon estimates tend to overestimate home ranges because they are affected by peripheral locations. However, when individuals use a relatively limited space, kernel areas can be even higher than those of MCP (Rechisky \& Wetherbee 2003). In our study, the selection of kernel bandwidth allowed us to incorporate the uncertainty of positional errors into home range estimates. The resulting spatial accuracy did not allow fine move- 
ments to be determined at a small scale that would correspond with microhabitat preferences. However, the design of the array allowed us to identify different patterns of movement, from highly resident movements to more nomadic behaviour.

Our results contrast with other studies conducted with other Serranid species with a larger body size. Home range estimates for Serranus scriba were higher than those reported for Plectropomus leopardus (10 458.4 to $18796.9 \mathrm{~m}^{2}$, Zeller 1997), Epinephelus guttatus (112 to $5636 \mathrm{~m}^{2}$, Shapiro et al. 1994) and Paralabrax clathratus (33 to $11224 \mathrm{~m}^{2}$, Lowe et al. 2003), while they were within the range of movement estimated for E. tauvina (70000 to $730000 \mathrm{~m}^{2}$, KaundaArara \& Rose 2004). If we take into account the fact that smaller Serranids may have a weaker relationship with bottom features on a microhabitat scale than larger Serranids (La Mesa et al. 2002), it is plausible that the activity space of $S$. scriba could be even higher than that of bigger Serranids.

Serranus scriba presented intraspecific variability both in temporal and spatial patterns. The detection of diel patterns should be taken into consideration when designing monitoring surveys to estimate abundance for this species. Moreover, the small home range of $S$. scriba supports the use of this fish as a bioindicator of human impacts (e.g. marine pollution or recreational fishing overexploitation). Home ranges of resident adult S. scriba were intermediate (average 12.4\% according to MCP; $55 \%$ according to $95 \%$ KUD) in relation to the size of the integral zone of the PBMR, and small (average $0.01 \%$ according to $\mathrm{MCP} ; 0.05 \%$ according to $95 \%$ KUD) in relation to the buffer zone of the PBMR. In addition, our data suggest that $36 \%$ of the fish studied exhibited a more mobile behaviour. Limitations in determining whether those fish relocated beyond the monitoring area or the MPA do not allow us to clearly demonstrate a net export to adjacent fishing grounds. However, our data support the hypothesis that PBMR could benefit the adjacent fished areas. If the fish tracked and home range sizes determined in this study were representative of other adults within the PBMR and over longer periods, then it is likely that: (1) the size of the integral zone would be enough to contain a high proportion of the regular movements of $S$. scriba but also allow cross-boundary movements to the buffer zone; (2) the size of the buffer zone could be effective in recovering the resident adult stock of S. scriba but would restrict adult spillover to the areas close to reserve borders. Further research to integrate spatially explicit models of fishing effort and fish abundance within the PMBR would refine the understanding of processes such as spillover.

Our results provided new information regarding the biology of Serranus scriba. Future long-term monitor- ing studies aimed at determining residence over extended periods through heterogeneous habitat would further improve our understanding of spatiotemporal patterns and habitat requirements of $S$. scriba, and the implications of these studies would provide a better assessment of the recreational fishery and the management of MPAs.

Acknowledgements. We thank the many people that collaborated in this project, particularly A.M. Grau, S. Martino, B. Morales-Nin, A. Álvarez, M. Martínez, M. Cabanellas, M. Linde and all voluntary anglers. We thank the technical support given by Sonotronics Inc. The habitat map was obtained from the LIFE Posidonia program, Government of the Balearic Islands. This study was financed by the project ROQUER (CTM2005-00283) funded by the Spanish Ministry of Research and Science, and by the research project ACOUSTIC TRACKING (UGIZC) founded by Government of the Balearic Islands. Authors D.M. and F.C. had a fellowship supported by the Spanish Ministry of Research and Science (BES-2006-13252) and the Government of the Balearic Islands, respectively. This study was carried out with a permission from the fisheries local administration, Government of the Balearic Islands, for fish tagging and receiver deployment at PBMR.

\section{LITERATURE CITED}

Abecasis D, Erzini K (2008) Site fidelity and movements of gilthead sea bream (Sparus aurata) in a coastal lagoon (Ria Formosa, Portugal). Estuar Coast Shelf Sci 79:758-763

Alós J (2008) Influence of anatomical hooking depth, capture depth, and venting on mortality of painted comber (Serranus scriba) released by recreational anglers. ICES J Mar Sci 65:1620-1625

Arculeo M, Froglia C, Riggio S (1993) Food partitioning between Serranus scriba and Scorpaena porcus (Perciformes) of the infralittoral ground of the South Tyrrhenian Sea. Cybium 17:251-258

Azzurro E, Pais A, Consoli P, Andaloro F (2007) Evaluating day-night changes in shallow Mediterranean rocky reef fish assemblages by visual census. Mar Biol 151: 2245-2253

Bartholomew A, Bohnsack J, Smith S, Ault J, Harper D, McClellan D (2008) Influence of marine reserve size and boundary length on the initial response of exploited reef fishes in the Florida Keys National Marine Sanctuary, USA. Landscape Ecol 23:55-65

Bauchot ML (1987) Serranidae. In: Fisher W, Bauchot ML, Scheneider $M$ (eds) Fiches FAO d'identification des espèces pour les besoins de la pêche. (Révision 1), Méditerranée et Mer Noire, Vértebrés, Vol II. FAO-CEE, Rome, p 1301-1319

Botsford LW, Brumbaugh DR, Grimes C, Kellner JB and others (2009) Connectivity, sustainability, and yield: bridging the gap between conventional fisheries management and marine protected areas. Rev Fish Biol Fish 19:69-95

Bowman AW, Azzalini A (1997) Applied smoothing techniques for data analysis: the kernel approach with S-Plus illustrations. Oxford University Press, Oxford

Burger J, Gochfeld M (2001) On developing bioindicators for human and ecological health. Environ Monit Assess 66: $23-46$

Calenge C (2006) The package 'adehabitat' for the R software: a tool for the analysis of space and habitat use by animals. Ecol Modell 197:516-519 
Cardona L, Lopez D, Sales M, De Caralt S, Diez I (2007) Effects of recreational fishing on three fish species from the Posidonia oceanica meadows off Minorca (Balearic archipelago, western Mediterranean). Sci Mar 71:811-820

Collins AB, Heupel MR, Motta PJ (2007) Residence and movement patterns of cownose rays Rhinoptera bonasus within a south-west Florida estuary. J Fish Biol 71: $1159-1178$

Fasola M, Canova L, Foschi F, Novelli O, Bressan M (1997) Resources use by a Mediterranean rocky slope fish assemblage. PSZNI: Mar Ecol 18:51-66

Fischer EA, Petersen CW (1987) The evolution of sexual patterns in the seabasses. Bioscience 37:482-489

Francour P (2000) Long term monitoring of Posidonia oceanica fish assemblages of the Scandola Marine Reserve (Corsica, northwestern Mediterranean). Cybium 24:85-95

Guidetti P (2000) Differences among fish assemblages associated with nearshore Posidonia oceanica seagrass beds, rocky-algal reefs and unvegetated sand habitats in the Adriatic Sea. Estuar Coast Shelf Sci 50:515-529

Harmelin JG (1987) Structure and variability of the icthyofauna in a Mediterranean protected rocky area (National park of Port Cros, France). PSZN I:Mar Ecol 8:263-284

> Hedger RD, Martin F, Dodson JJ, Hatin D, Caron F, Whoriskey FG (2008) The optimized interpolation of fish positions and speeds in an array of fixed acoustic receivers. ICES J Mar Sci 65:1248-1259

- Heupel MR, Semmens JM, Hobday AJ (2006) Automated acoustic tracking of aquatic animals: scales, design and deployment of listening station arrays. Mar Freshw Res 57: $1-13$

Jadot C, Donnay A, Acolas ML, Cornet Y, Anras MLB (2006) Activity patterns, home-range size, and habitat utilization of Sarpa salpa (Teleostei: Sparidae) in the Mediterranean Sea. ICES J Mar Sci 63:128-139

> Jorgensen SJ, Kaplan DM, Klimley AP, Morgan SG, O'Farrell MR, Botsford LW (2006) Limited movement in blue rockfish Sebastes mystinus: internal structure of home range. Mar Ecol Prog Ser 327:157-170

Kaunda-Arara B, Rose GA (2004) Homing and site fidelity in the greasy grouper Epinephelus tauvina (Serranidae) within a Marine protected area in coastal Kenya. Mar Ecol Prog Ser 277:245-251

Kramer DL, Chapman MR (1999) Implications of fish home range size and relocation for marine reserve function. Environ Biol Fishes 55:65-79

La Mesa G, Louisy P, Vacchi M (2002) Assessment of microhabitat preferences in juvenile dusky grouper (Epinephelus marginatus) by visual sampling. Mar Biol 140:175-185

Laver PN, Kelly MJ (2008) A critical review of home range studies. J Wildl Manag 72:290-298

Lowe CG, Topping DT, Cartamil DP, Papastamatiou YP (2003) Movement patterns, home range, and habitat utilization of adult kelp bass Paralabrax clathratus in a temperate notake marine reserve. Mar Ecol Prog Ser 256:205-216

Maraun D, Kurths J, Holschneider M (2007) Nonstationary Gaussian processes in wavelet domain: Synthesis, estimation, and significance testing. Phys Rev E Stat Nonlin Soft Matter Phys 75:016707-016714

- Miksis-Olds JL, Miller JH (2006) Transmission loss in manatee habitats. J Acoust Soc Am 120:2320-2327

> Morales-Nin B, Moranta J, Garcia C, Tugores MP, Grau AM, Riera F, Cerda M (2005) The recreational fishery off Majorca Island (western Mediterranean): some implications for coastal resource management. ICES J Mar Sci 62: 727-739

Morato T, Santos RS, Andrade JP (2000) Feeding habits, sea- sonal and ontogenetic diet shift of blacktail comber, Serranus atricauda (Pisces: Serranidae), from the Azores, north-eastern Atlantic. Fish Res 49:51-59

> Naylor E (2005) Chronobiology: implications for marine resource exploitation and management. Sci Mar 69: 157-167

> Parsons D, Egli D (2005) Fish movement in a temperate marine reserve: new insights through application of acoustic tracking. Mar Technol Soc J 39:56-63

Percival D, Walden A (2000) Wavelet methods for time series analysis. Cambridge University Press, Cambridge

Pittman SJ, McAlpine CA (2003) Movements of marine fish and decapod crustaceans: process, theory and application. Adv Mar Biol 44:205-294

> Rechisky EL, Wetherbee BM (2003) Short-term movements of juvenile and neonate sandbar sharks, Carcharhinus plumbeus, on their nursery grounds in Delaware Bay. Environ Biol Fishes 68:113-128

> Reebs SG (2002) Plasticity of diel and circadian activity rhythms in fishes. Rev Fish Biol Fish 12:349-371

Reñones O, Massuti E, Moranta J, Coll J, Moreno I (1995) Fish fauna of Posidonia oceanica seagrass meadows in Palma Bay (Balearic Islands). Cybium 19:201-206

Roméo M, Siau Y, Sidoumou Z, Gnassia-Barelli M (1999) Heavy metal distribution in different fish species from the Mauritania coast. Sci Total Environ 232:169-175

Sale PF, Cowen RK, Danilowicz BS, Jones GP and others (2005) Critical science gaps impede use of no-take fishery reserves. Trends Ecol Evol 20:74-80

Shapiro D, Garcia-Moliner G, Sadovy Y (1994) Social system of an inshore stock of the red hind grouper, Epinephelus guttatus (Pisces: Serranidae). Environ Biol Fishes 41: $415-422$

Simpfendorfer CA, Heupel MR, Hueter RE (2002) Estimation of short-term centers of activity from an array of omnidirectional hydrophones and its use in studying animal movements. Can J Fish Aquat Sci 59:23-32

Subbey S, Michalsen K, Nilsen GK (2008) A tool for analyzing information from data storage tags: the continuous wavelet transform (CWT). Rev Fish Biol Fish 18:301-312

Taylor MD, Laffan SD, Fielder DS, Suthers IM (2006) Key habitat and home range of mulloway Argyrosomus japonicus in a south-east Australian estuary: finding the estuarine niche to optimise stocking. Mar Ecol Prog Ser 328: 237-247

Topping DT, Lowe CG, Caselle JE (2005) Home range and habitat utilization of adult California sheephead, Semicossyphus pulcher (Labridae), in a temperate no-take marine reserve. Mar Biol 147:301-311

> Topping DT, Lowe CG, Caselle JE (2006) Site fidelity and seasonal movement patterns of adult California sheephead Semicossyphus pulcher (Labridae): an acoustic monitoring study. Mar Ecol Prog Ser 326:257-267

Tortonese E (1986) Serranidae. In: Whitehead PJP, Bauchot ML, Hureau JC, Nielsen J, Tortonese E (eds) Fishes of the Northeastern Atlantic and the Mediterranean, Vol 2. United Nations Educational, Scientific and Cultural Organization (UNESCO), Paris, p 780-792

Voegeli FA, Smale MJ, Webber DM, Andrade Y, O'Dor RK (2001) Ultrasonic telemetry, tracking and automated monitoring technology for sharks. Environ Biol Fishes 60: $267-281$

Willis TJ, Badalamenti F, Milazzo M (2006) Diel variability in counts of reef fishes and its implications for monitoring. J Exp Mar Biol Ecol 331:108-120

Zeller DC (1997) Home range and activity patterns of the coral trout Plectropomus leopardus (Serranidae). Mar Ecol Prog Ser 154:65-77 